\title{
May and might in nineteenth century Irish English and English English
}

\section{Document Version}

Accepted author manuscript

Link to publication record in Manchester Research Explorer

\section{Citation for published version (APA):}

Van Hattum, M. (2015). May and might in nineteenth century Irish English and English English. In P. Collins (Ed.), Grammatical Change in English World-Wide: Studies in Corpus Linguistics (Vol. 67, pp. 221-246). John Benjamins Publishing Company.

\section{Published in:}

Grammatical Change in English World-Wide

\section{Citing this paper}

Please note that where the full-text provided on Manchester Research Explorer is the Author Accepted Manuscript or Proof version this may differ from the final Published version. If citing, it is advised that you check and use the publisher's definitive version.

\section{General rights}

Copyright and moral rights for the publications made accessible in the Research Explorer are retained by the authors and/or other copyright owners and it is a condition of accessing publications that users recognise and abide by the legal requirements associated with these rights.

\section{Takedown policy}

If you believe that this document breaches copyright please refer to the University of Manchester's Takedown Procedures [http://man.ac.uk/04Y6Bo] or contact uml.scholarlycommunications@manchester.ac.uk providing relevant details, so we can investigate your claim.

\section{OPEN ACCESS}


May and might in nineteenth-century Irish English and English English *

Marije Van Hattum

Université de Lausanne

\begin{abstract}
This paper discusses the use of may and might in $19^{\text {th }}$ century Irish English and English English. It builds on Van Hattum (2012a), which found that in $18^{\text {th }}$ and $19^{\text {th }}$ century Irish English might Vinf was used in contexts requiring may/might have Ven in present-day English. This paper aims to find out if this development is due to regional or diachronic variation via a corpus-based study of these modals in $19^{\text {th }}$ century Irish English and English English. The data shows no change in objective possibility contexts, but in subjective possibility contexts might loses the ability to signal past time. Though the data show some small differences between Irish English and English English, generally it seems that the change identified in Van Hattum (2012a) is due to diachronic variation.
\end{abstract}

\title{
1. Introduction
}

\footnotetext{
* I would like to thank David Denison, Peter Collins and two anonymous reviewers for their helpful comments on earlier versions of this paper. Any remaining errors are, of course, my own.
} 
Both the diachronic development of modal verbs and the grammaticalisation of the perfect constructions have received widespread attention in English English (EngE) ${ }^{1}$, and much research has been done over the past couple of decades on modal verbs and perfects in present-day varieties of English. However, when studying the perfect in varieties of English, constructions with modal verbs are sometimes disregarded on the grounds that no variation between preterite and perfect constructions is possible, and that a modal + perfect construction is used in both simple past and present perfect contexts. In a study of modal verbs and past time reference in $19^{\text {th }}$ century Irish English (IrE), Van Hattum (2012a) found that there is variation between a preterite construction and a perfect construction in verb groups that contain a modal verb and that in present-day English (PDE) would require a modal + perfect construction. The paper discussed examples such as (1), where a past tense modal verb is followed by the infinitive of the lexical verb, instead of have followed by a past participle, as would be expected in standard PDE. ${ }^{2}$ It was found that this construction could occur both in counterfactual sentences that signal the non-occurrence of an event in the past, such as (1) where something might happen - my head might be broken can be paraphrased by 'it is possible that something would have happened - it is possible that my head would have been broken', and in

\footnotetext{
${ }^{1}$ In this paper I use the term 'English English' to refer to varieties of English as spoken in England. The use of this term in favour of the more common term British English allows me to exclude other varieties of English which would be considered part of British English, such as Scottish English.

${ }^{2}$ In order to avoid confusion between semantic tense and morphological tense, I will use time for the former and tense for the latter.
} 
subjective possibility contexts, commonly known as epistemic possibility, such as (2), where we might have a storm or 3 since can be paraphrased by 'it is possible that we have had a storm or 3 since'. However, Van Hattum (2012a) could not determine whether the occurrence of sentences such as (1) and (2) was due to regional differences between IrE and EngE, or due to diachronic differences between $19^{\text {th }}$ and $20^{\text {th }}$ century English.

(1) I put my name to it to keep a row from rising - that was the only reason - if I had not put my name to it there would be a row, and something might happen - my head might be broken (OBC, Cook 1874)

(2) We might have a storm or 3 since, but not a wet day (OC Burke 1884)

The majority of tokens for the constructions mentioned above occurred with may and might. Previous research has suggested that two important developments with regards to may and might took place from the $18^{\text {th }}$ to the $21^{\text {st }}$ centuries: (i) might established itself as an independent modal verb which came to express subjective possibility in non-past contexts, as in (3), where it might sound rotten can be paraphrased by it is possible that it sounds rotten'; and (ii) a modal + perfect construction became obligatory in order to express past time reference with epistemic and counterfactual modal verbs, as in (4), where he may have had an accident can be 
paraphrased by 'it is possible that he had an accident'. These changes suggest that might lost its ability to signal past time reference and that may and might became interchangeable. However, it is not known exactly when these new constructions were formed and how frequently they were used in contrast with older constructions throughout this period. The present paper investigates the use of modal verbs may and might in past time contexts in $19^{\text {th }}$ century IrE and EngE, in order to establish whether some of the findings in Van Hattum (2012a) were due to regional differences between IrE and EngE, diachronic differences between $19^{\text {th }}$ and $20^{\text {th }}$ century English, or perhaps both. In other words, it aims to investigate the ability of might to signal past time reference in the $19^{\text {th }}$ century in order to see whether the PDE norms as laid out in works such as Coates (1983), Palmer (1990), Condoravdi (2000), and Demirdache \& Uribe-Etxebarria (2008) had already been established.

(3) It might sound rotten, but I don't feel sorry for him (OED, s.v. may $\left.\mathrm{v}^{1}, 26 \mathrm{c}\right)$

(4) He isn't back yet; He may have had an accident (Visser 1969: 1774)

In order to achieve this aim, the modal verbs may and might are investigated by means of a corpus-based analysis of $19^{\text {th }}$ century IrE and EngE trial proceedings and personal letters. Trials proceedings are 
particularly suitable for this study because in trials participants are asked to form judgements about the possibility of events that have happened in the past. Thus, it is expected that these text types will yield a large number of subjective possibility contexts with past time reference. Emigrant letters were chosen because they provide insights into local, non-standard language use, as they contain instances of informal, intimate and relatively unmonitored language use (Fritz 2007). My reasons for deciding on the $19^{\text {th }}$ century are two-fold: (i) Filppula (1999) argues that the $19^{\text {th }}$ century provides the foundation of present-day IrE grammar; and (ii) Van Hattum (2012b) has shown that the most significant differences between the use of modal verbs in IrE and EngE were visible in the $19^{\text {th }}$ century. The changing state of IrE in the $19^{\text {th }}$ century has often been attributed to the large increase in native Irish speakers shifting to English in their daily life. Among some of the major factors involved in the acceleration of the language shift were the Great Famine of the 1840s and the introduction of the National School System in 1833.

The paper starts by discussing previous research on the development of the expression of time reference with may and might in standard EngE (Section 2). In Section 3, I provide an overview of the corpora used for this study and Section 4 presents the analysis of the tokens retrieved from the corpora. A discussion of the results is offered in Section 5, and the final section discusses the implications of the findings with respect to the research aim as laid out in the introduction. 


\section{Historical development of past time reference with may and might}

The PDE group of core modal verbs (i.e. can, could, may, might, must, shall, should, will, and would) have had morpho-syntactic characteristics which set them apart from other verbs since the Old English (OE) period. ${ }^{3}$ Among these behavioural properties is the use of past tense forms without past time reference and outside a motivating context (Warner 1993), as can be seen in example (5). Here the past tense form of the OE pre-modal magan appears in the protasis of a conditional sentence and is used to indicate a hypothetical, or remote, meaning. Thus, it seems that from an early stage in the development of the English language onwards, the relationship between past time reference and (pre-)modal verbs has been far from straightforward. The following section will discuss previous research on the development of time reference in clauses with the (pre-)modal verbs may and might in two different contexts, objective possibility and subjective possibility, as it is in these two contexts that an obligatory perfect construction to indicate past time reference develops.

\footnotetext{
${ }^{3}$ For a more detailed account of the morphosyntactic development of (pre-)modal verbs, see Visser (1969), Traugott (1972), Lightfoot (1979), Denison (1993) and Warner (1993).
} 
Æ[lc cy]ninc wolde bion butan pissum, [\& hab]ban peah anwald gif he meahte; æc ic wat pæt hi ne mæg (OED, s.v. may $\left.\mathrm{v}^{1}, 20 \mathrm{a}\right)$ 'every king would be quit of these and yet hold power if he could, but I know he cannot' (Sedgefield 1900: 71)

\subsection{Objective possibility}

The (pre-)modal verb MAY has been used in objective possibility contexts where an external source enables a proposition to take place since at least the OE period (Visser 1969, Traugott 1972, Traugott 2006, Dollinger 2008). What is referred to in this paper as objective possibility has also been termed 'root' (Coates 1983, Dollinger 2008,), 'dynamic existential' (Facchinetti 2003), 'dynamic' (Palmer 1990) and 'participant-external' (Van der Auwera \& Plungian 1998) possibility. When expressing objective possibility, may can be paraphrased by 'it is possible for ...', as in example (6). Objective possibility is different from what has been termed 'deontic' possibility, or permission, in which the external sources which enable the proposition to take place can be found in a person, moral value or law. It is also different from subjective possibility which concerns a speaker judgement about the possibility of an event taking place (see Section 2.2). Whereas objective possibility is generally paraphrased by 'it is possible for ...', subjective possibility is often paraphrased by 'it is possible that ...'. 
(6) Cader Idris, however, may be climbed from other points on this tour (Palmer 1990: 109)

Might followed by an infinitive form of the lexical verb has been used to signal past time reference and remoteness since the $\mathrm{OE}$ period. When expressing past time reference, as in example (7), might can be paraphrased by 'it was possible for ...', and when expressing remoteness, as in example (8), might can be paraphrased by 'it would be possible for ...'. The fact that might can be used to signal both past time and remoteness means that the interpretation of the time reference of the modal verb is dependent on the context. Thus, when might occurs with a past time interpretation, it frequently occurs in contexts which follow sequence-of-tense rules, as in example (7).

(7) ... one of our town ... had given out that there was a private room within Gilling Castle where forty men might be concealed (Coates 1983: 147)

(8) We operate what might be described as a gigantic tutorial system (Coates 1983: 147)

The data in Visser (1969: 1774-1777) and the OED (s.v. may $\left.v^{1}, 20 b\right)$ suggest that during the Middle English (ME) period the might have Ven 
construction developed to signal a possibility in relation to the past of which we know the envisaged result did not come about. In example (9), he myzt a forsake can be paraphrased by 'it would have been possible for him to forsake', and the rest of the context suggests that he in fact did not forsake. In counterfactual contexts such as these, the perfect is said to create a backshifted interpretation relative to the time of the utterance and the perfect has scope over the modal verb as the modal verb is 'tenseless'; that is, it does not have the ability to signal past time reference, possibly due to its remote interpretation (Condoravdi 2002, Demirdache \& Uribe-Etxebarria 2008).

(9) He myzt a forsake, and seyd nay, But whan he toke hyt, he brake pe lay (Visser 1969:1776)

'He might have forsaken, and said no, but when he took it, he broke the peace'

\subsection{Subjective possibility}

Subjective possibility concerns speaker judgements of the possibility or uncertainty of the truth-value of a statement and can be paraphrased by 'it is possible that...'. For instance, example (10) can be read as 'it is possible that I will be a few minutes late', and this interpretation is verified by the cooccurrence with I don't know. Previous research on the history of may and might suggests that the development of a subjective possibility meaning for 
these verbs probably started in the OE period, but this meaning was not fully established until the $14^{\text {th }}$ century (Visser 1969, Traugott 1972, 2006, Dollinger 2008). As with objective possibility, might Vinf can be used to signal remote meaning or past time reference (though in PDE only in sequence-of-tense contexts), as in examples (11), where might can be paraphrased by 'it would be possible for' and (12), where might can be paraphrased by 'it was possible that'.

(10) I may be a few minutes late, but I don't know (Coates 1983:132)

(11) But if he wished to do it, it might be done (OED, s.v. may $\mathrm{v}^{1}$, 20a)

(12) He began to reflect that in a few Minutes he might possibly deprive a human Being of Life, or might lose his own (OED, S.v. $\left.\operatorname{may} \mathrm{v}^{1}, 18 \mathrm{a}\right)$

In PDE, modal verbs with subjective possibility interpretations can express past and present time independently of the time reference of the proposition. Example (13) can be paraphrased by 'it is possible that he was there while you were there', which indicates that the time of the modality is non-past, whereas the time of the proposition is past (Palmer 1990). In earlier forms of English, might Vinf could be used to signal past time, both in sequence-of-tense contexts, where both the modality and the proposition 
have past time reference (e.g. example (12) above), and in expressions of present possibilities of past situations, as in example (14). According to the OED (s.v. may $\mathrm{v}^{1}, 18 \mathrm{~b}$ ) this might Vinf construction in the latter context is now rare or even obsolete and has been superseded by may have Ven. The first quotation for this construction in the OED, example (15), is dated to 1425. The OED suggests that another variant, might have Ven, arose in the $19^{\text {th }}$ century, though Visser (1969) maintains that might have Ven is only used to signal counterfactuality. The first quotation for this construction in the OED, example (16), which dates to 1847 , seems still to be linked with a counterfactual context. The first part of the sentence is clearly counterfactual, as the officer was prevented from planting a kiss, but the speculations about the woman's motivations for averting the kiss are not counterfactual. The OED proposes that this use developed from might Vinf in hypothetical statements when the condition is implied by the context, as in example (17).

(13) He might have been there while you were there (Palmer 1990: 64)

(14) After all, these two respectable writers might not intend the mischief they were doing (Visser 1969: 1773)

(15) For as muche as the seurtees of yis said somme .. may not have beene engrossed (OED, s.v. may $\left.\mathrm{v}^{1}, 7 \mathrm{c}\right)$ 
(16) The gallant officer ... would have imprinted a kiss on her ... lips, but for her interposing the fan ... It might have been in modesty; it might have been in apprehension of some danger to their bloom (OED, s.v. may $\left.\mathrm{v}^{1}, 26 \mathrm{a}\right)$

(17) The same doubts might be started respecting, respecting the nature of water (OED, s.v. may $\left.v^{1}, 21 \mathrm{a}\right)$

An important methodological issue in analysing the capacity of may and might to signal past or non-past time reference is to identify all the contexts in which variation in forms with may and might is possible. The literature discussed above suggests that two features are involved in the selection of forms with may and might for the expression of objective and subjective possibility may and might: (i) \pm past and (ii) \pm remote. The time reference and the remoteness can affect the modality and the proposition, as is the case with objective possibility modals, or the proposition only, as is the case with subjective possibility modals. The combination of these features results in the contexts displayed in examples (18) and (19). ${ }^{4}$

objective possibility

\footnotetext{
${ }^{4}$ Though theoretically speaking more combinations in subjective possibility contexts are possible, they are very infrequent and were not found in the corpus under investigation. Therefore, they have been excluded from the list.
} 
a. $-P /$ past - remote $e^{5}$

You may find inclosed a small lock of your Father's gray hair

(CVC, Buckley 1847)

b. $\quad-P /$ past + remote

Had we a station now we might be saving money (COOEE, Selby 1846)

c. $\quad+P /$ past - remote

Challier wished to have the chalk marks rubbed off that it might look older (OBC, T18750816)

d. $\quad+$ P/past + remote

He might have had work long since here, if he had a mind too (CVC, Buckley 1847)

(19) subjective possibility

a. $-M /$ past $-P /$ past-remote

as we all must die sooner or later it is possable that some of them may drop off (OC, McCance 1861)

b. $-M /$ past $-P /$ past +remote

You might see something new in them if you got none from any other (OC, McCance 1862)

c. $-M /$ past $+P /$ past - remote

\footnotetext{
${ }^{5}$ The symbolisation suggests whether the propositions of the examples are past $(+\mathrm{P} / \mathrm{past})$, non-past ( $-P /$ past), remote (+remote) or non-remote (-remote) and whether the time of the modality is past $(+\mathrm{M} /$ past $)$ or non-past $(-\mathrm{M} /$ past $)$.
} 
There may have been four or five persons present (OBC, T18750920)

d. + M/past + P/past - remote

Dale said that I might have given it to him, he did not recollect (OBC, T18580705)

\section{Sources}

The tokens used in this paper were part of my investigation into the development of modal verbs in IrE from the $14^{\text {th }}$ century to the present day (Van Hattum 2012b), which made use of a self-compiled corpus of historical Irish English. The relevant section of the corpus consisted of approximately 400,000 words compiled from three sources: the CORIECOR corpus (McCafferty \& Amador-Moreno, under construction), the book Oceans of Consolation by Fitzpatrick (OC) (1994), and the Old Bailey Corpus (OBC) (Huber et al. 2012). The Corpus of Irish English Correspondence (CORIECOR), compiled by Kevin McCafferty and Carolina P. Amador-Moreno at the Universities of Bergen and Extremadura, is a corpus of personal letters written by speakers of IrE from 1740 to 1940 . Approximately 170,000 words were selected from this corpus on the basis 
of their socio-biographical mark-up. ${ }^{6}$ Fitzpatrick (1994) provides a collection of approximately 80,000 words of private correspondence written by Irish settlers in Australia and their families and friends back home in the north and south of Ireland in the $19^{\text {th }}$ century. The $\mathrm{OBC}$ is a diachronic corpus of trial proceedings based on the transcripts of the Old Bailey in London (Hitchcock et al. 2012), covering a time span from the late $17^{\text {th }}$ to the early $20^{\text {th }}$ centuries. The Irish English speakers were identified by searching for the terms 'Irish' and 'Ireland' and checking whether the participants identified themselves as being Irish or were identified as Irish by others in the trial. This helped isolate over 150,000 words by 397 informants from various parts of Ireland (Northern Ireland and the Republic) and various social classes (lower, middle and upper).

Where possible, this paper aims to determine whether the development of objective and subjective possibility may and might in IrE differs from the development in EngE. Thus, the IrE data were compared to a similar corpus of EngE letters and trial proceedings. The materials were again drawn from the Old Bailey Corpus, supplemented with the Cherry Valley Chronicles (Dennett 1990), English emigrant letters from the corpus of $O z$ Early English (COOEE, Fritz 2004), and the letter genre of the ARCHER 3.1 corpus. ${ }^{7}$ I only considered texts which met the following criteria: (i) texts produced between 1800 and 1899; (ii) texts classifiable as either personal

\footnotetext{
${ }^{6}$ For more information on the corpus and its compilation, see Van Hattum (2012b).

${ }^{7}$ For more information on the individual EngE sources I refer the reader to Dennett (1990), Fritz (2007) and Yáñez-Bouza (2011).
} 
correspondence or trial proceeding; and (iii) texts representing the speech or writing of someone who was born (and educated) in England. ${ }^{8}$ To prevent idiolectal bias, no more than 5,000 words per informant were selected. This resulted in a total of approximately 95,000 words of letters. To retrieve EngE tokens from the OBC I considered the full corpus. In order to make the coding less time consuming, I decided to randomly extract fifty tokens per modal verb per 25-year period. In order to avoid duplication, I ensured none of the tokens which were already represented in the IrE subcorpus had been selected. For the purpose of this paper, I deleted all instances which did not have an objective or subjective possibility meaning.

Table 1 Overview of sources used for IrE and EngE

\begin{tabular}{lllll}
\hline Variety & Source & Text type & Timespan & Words \\
\hline IrE & CORIECOR & Emigrant letters & C $18^{\text {th }}$ and $19^{\text {th }}$ & $\pm 170,000$ \\
& & Personal letters & \\
& OC & Emigrant letters & $C 19^{\text {th }}$ & $\pm 80,00$ \\
& OBC & trial proceedings & $C 18^{\text {th }}$ and $19^{\text {th }}$ & $\pm 150,000$ \\
& Total & & & $\pm 400,000$ \\
EngE & CVC & emigrant letters & $C 19^{\text {th }}$ & $\pm 16,000$ \\
& COOEE & emigrant letters & $C 19^{\text {th }}$ & $\pm 70,000$ \\
& ARCHER & personal letters & $C 19^{\text {th }}$ & $\pm 9,000$
\end{tabular}

\footnotetext{
${ }^{8}$ For a discussion of the transcription processes of the trial proceedings and the reliability of these transcripts, please see Huber (2007).
} 


\section{Results}

Table 2Table 2 shows the frequencies of may and might with objective and subjective possibility meanings per context. There were a total of $249 \mathrm{IrE}$ and 411 EngE tokens, split across the eight different contexts as laid out in Section 2. Each of these contexts will now be discussed in turn, and where the data allow, diachronic patterns and regional differences between EngE and IrE will be analysed.

Table 2. May and might in $19^{\text {th }}$ century IrE and EngE

\begin{tabular}{lccc}
\hline Context & IrE & EngE & Total \\
\hline Objective possibility & & & \\
-past -remote & 51 & 66 & 117 \\
-past +remote & 11 & 17 & 28 \\
+past -remote & 8 & 17 & 25 \\
+ past + remote & 11 & 18 & 29
\end{tabular}


Subjective possibility

\begin{tabular}{lccc}
$-\mathrm{M} /$ past $-\mathrm{P} /$ past -remote & 99 & 100 & 199 \\
$-\mathrm{M} /$ past $-\mathrm{P} /$ past +remote & 15 & 14 & 29 \\
$-\mathrm{M} /$ past +P/past -remote & 36 & 158 & 194 \\
$+\mathrm{M} /$ past +P/past -remote & 18 & 21 & 39 \\
Total & 249 & 411 & 660 \\
\hline
\end{tabular}

\subsection{Objective possibility}

\subsection{1-P/past-remote}

In non-past, non-remote objective possibility contexts the expected form of the verb group is may Vinf. Several different forms were grouped together under the term may Vinf: (i) instances where may is followed directly by the infinitive form of the lexical verb, as in example (20); (ii) instances where may is followed by be and the -ing form of the lexical verb, as in example (21); and (iii) instances where may is followed by be and the past participle of the lexical verb, as in example (22). As mentioned in Section 2, in objective possibility contexts the time of the modality coincides with the time of the proposition. Thus, the present tense form of may in these instances signals that both the objective possibility and the proposition are non-past. 
(20) My dearest Mother, I have left out my desk that I may scribble to the last moment (COOEE, Bussell 1833)

(21) $\quad$... and let my friend Mr. Chambers see this note, so that he may be preparing also (CORIECOR, Howard 1871)

(22) We purchased a mare and colt for 150 pounds that in England may be got for about 20 pounds each (COOEE, Viveash 1839)

The corpus also includes instances where this context is expressed by might Vinf, as in example (23). However, all instances of might Vinf in this context seem to occur in formulaic expressions similar to I might say and I might mention. Might is not the only modal verb that can occur in these expressions. The corpus records instances with can, could, may, must, shall, will, and would. It seems that in these instances might has undergone semantic bleaching and has lost its function as either a past time or a remoteness marker. In addition, the meaning of objective possibility is only minimally present in these instances. Instead, it seems that formulaic phrases such as I might say have become pragmatic markers. As can be seen in Table 3, the pragmatic marker with might occurs slightly more frequently in $\operatorname{IrE}$ in comparison to $\operatorname{EngE}\left(\mathrm{X}^{2}=7.216, d f=1, p=0.007\right)$.

(23) Her dear Children ar all getting on so nicely and as I might say ar Helthy (OC Wyly 1857) 
Table 3. May and might in objective possibility contexts

\begin{tabular}{|c|c|c|c|c|}
\hline Context & \multicolumn{2}{|l|}{ IrE } & \multicolumn{2}{|c|}{ EngE } \\
\hline \multicolumn{5}{|l|}{-past-remote } \\
\hline may Vinf & 42 & $(82 \%)$ & 64 & $(97 \%)$ \\
\hline might Vinf & 9 & $(18 \%)$ & 2 & $(3 \%)$ \\
\hline \multicolumn{5}{|l|}{-past +remote } \\
\hline may Vinf & 2 & $(18 \%)$ & 2 & $(12 \%)$ \\
\hline might Vinf & 9 & $(82 \%)$ & 15 & $(88 \%)$ \\
\hline \multicolumn{5}{|l|}{+ past - remote } \\
\hline might Vinf & 8 & $(100 \%)$ & 17 & $(100 \%)$ \\
\hline \multicolumn{5}{|l|}{+ past +remote } \\
\hline might Vinf & 2 & $(18 \%)$ & 4 & $(22 \%)$ \\
\hline might have Ven & 9 & $(82 \%)$ & 14 & $(78 \%)$ \\
\hline
\end{tabular}

\subsection{2-P/past +remote}

In non-past, remote contexts the expected form is might Vinf, as in example (24), which includes passive and progressive constructions. This form is the majority variant in this context with a proportional distribution of $82 \%$ in $\mathrm{IrE}$ and $88 \%$ in EngE, as can be seen in

Table 3 above. These findings are in line with the existing literature, which claims that might is the remote form of MAY and can occur in nonpast contexts (see, for example, Visser 1969; Coates 1983; Palmer 1990). The form may Ving, as in example (25), is also recorded as a variant in this 
corpus, though it appears less frequently than might Ving, with a distribution of $18 \%$ in IrE and $12 \%$ in EngE. Thus, it seems that a remote context often triggers the use of might Vinf, but it is not obligatory. There is a small difference between the IrE and EngE dataset, but it is not statistically significant.

(24) I might tell you of they Neighbours but I do think the $1 / 3^{\text {rd }}$ of them are ded (OC, Hammond 1857)

(25) If you settle on this side the hills you may bring more furniture but I would not bring too much, it can be sent for (COOEE, Tanner 1839)

\subsection{3 +P/past-remote}

The corpus did not show any variation between competing forms in past, non-remote contexts, as can be seen in

Table 3 above. The only form found in this context is might Vinf, as in example (26). You might get as good a house can be paraphrased by 'it was possible for you to get as good a house', suggesting that might causes a past time reference for both the modality and the proposition. It should be noted that as the context only occurred 25 times, it is unlikely that any minority variants would have been recorded in a relatively small corpus such as the one used for this study. Nevertheless, the findings are in line with previous literature on the expression of objective possibility in past time contexts (see, for example, Visser 1969; Coates 1983; Palmer 1990). 
(26) You might get as good a house in Birmingham for 2s. 6d. per week when I left ... (COOEE, Parkes 1840)

4.1.4 +P/past + remote

Previous research suggests that might have Ven is used to express objective possibility in past remote contexts, and this form is indeed the majority variant in the corpus with a proportional distribution of $82 \%$ in $\operatorname{IrE}$ and $79 \%$ in EngE. All examples where might have Ven is used in this context have a counterfactual interpretation. Might have Ven can also occur with a reduced form of have, including $\varnothing$ have (Van Hattum 2012a), as in (27). This example can be read as 'it would have been possible for $\mathrm{Mr}$ Colhist to do equally as well as Foss'. According to Condoravdi (2002) and Demirdache \& Uribe-Etxebarria (2008), the modal verb in examples such as (27) does not have the ability to create a past time interpretation, so the perfect has scope over the modal verb as well as the proposition.

(27) had Mr Hargreaves sent them out within 15 or 18 months $\mathrm{Mr}$ Colhist whould have had no oponent and might equally done as well as Foss (COOEE, Reibey 1829) 
Though Condoravdi (2002) and Demirdache \& Uribe-Etxebarria (2008) consistently analyse counterfactuals as objective possibility, or 'metaphysical' in their terms, it is often unclear whether we are dealing with an objective or subjective possibility sense, or perhaps even a merger of the two (Coates 1983163-164; Denison 1992:234); for example, in (28) it is unclear whether might have fallen should be read as 'it is possible that it would have fallen' or 'it would have been possible for it to fall'. Thus, all instances of counterfactual readings have been grouped together and are discussed under objective possibility, but they might just as appropriately be discussed under subjective possibility.

(28) I could not have laid it down, it might have fallen out of bed (OBC, Judge 1847)

Another form that can be found in past remote objective possibility contexts is might Vinf, but in these examples there is no counterfactual interpretation. Instead, the examples appear in the apodosis of conditional sentences that follow sequence-of-tense rules, as in example (29). The example can be paraphrased by 'it was possible for him to see it' and the modal verb functions as a past tense and remoteness marker, though the interpretation is still dependent on the context as might Vinf can have other functions as well. 
(29) I left word that some flour was found, and was at the watchhouse, and if he came there he might see it; I think the answer I received was, "Very well;" after Mr. Aldridge was up I went to his house again - he came and saw the flour (OBC, T18260406)

\subsection{Subjective possibility}

\subsection{1 $-M /$ past $-P /$ past -remote}

Table 4 shows the distribution of may Vinf, may have Ven, might Vinf, and might have Ven in subjective possibility contexts. Two different forms can be found in the corpus to express non-past, non-remote subjective possibility: may Vinf, as in (30), and might Vinf, as in (31). In both varieties of English may Vinf is the majority variant with $78 \%$ and $88 \%$ in $\operatorname{IrE}$ and EngE, respectively. The minority variant might Vinf occurs somewhat more frequently in IrE than in EngE. The difference between the totals for IrE and EngE is marginally significant $\left(X^{2}=3.67, d f=1, p=0.06\right)$.

(30) I may know Ellen Harley, but I do not know that I do (OBC, Collins 1840)

(31) I might possibly be mistaken as to your being at my house (OBC, Lynch 1879) 
Table 4. May and might in subjective possibility contexts

\begin{tabular}{|c|c|c|c|c|}
\hline Context & \multicolumn{2}{|l|}{$\mathrm{IrE}$} & \multicolumn{2}{|c|}{ EngE } \\
\hline \multicolumn{5}{|c|}{-M/past -P/past -remote } \\
\hline may Vinf & 77 & $(78 \%)$ & 88 & $(88 \%)$ \\
\hline might Vinf & 22 & $(22 \%)$ & 12 & $(12 \%)$ \\
\hline \multicolumn{5}{|c|}{$-\mathrm{M} /$ past $-\mathrm{P} /$ past + remote } \\
\hline may Vinf & 4 & $(27 \%)$ & 8 & $(57 \%)$ \\
\hline might Vinf & 11 & $(73 \%)$ & 6 & $(43 \%)$ \\
\hline \multicolumn{5}{|c|}{$-\mathrm{M} /$ past $+\mathrm{P} /$ past - remote } \\
\hline may Vinf & 1 & $(3 \%)$ & 5 & $(3 \%)$ \\
\hline might Vinf & 13 & $(36 \%)$ & 42 & $(27 \%)$ \\
\hline may have Ven & 10 & $(28 \%)$ & 64 & $(41 \%)$ \\
\hline might have Ven & 12 & $(33 \%)$ & 47 & $(30 \%)$ \\
\hline \multicolumn{5}{|c|}{$+\mathrm{M} /$ past $+\mathrm{P} /$ past - remote } \\
\hline may Vinf & 0 & $(0 \%)$ & 1 & $(5 \%)$ \\
\hline might Vinf & 17 & $(94 \%)$ & 18 & $(86 \%)$ \\
\hline might have Ven & 1 & $(6 \%)$ & 2 & $(9 \%)$ \\
\hline
\end{tabular}

Figure 1 shows the development of the two variants may Vinf and might Vinf in subjective possibility contexts where the proposition is nonpast and non-remote throughout the $19^{\text {th }}$ century. The distribution of these 
variants in IrE and EngE seems to develop in opposite directions. In EngE, may Vinf is the most frequent variant at the start, but towards the end of the century gradually becomes less frequent in comparison to might Ving. The difference between EngE of the early and late $19^{\text {th }}$ century is statistically significant $\left(X^{2}=4.99, d f=1, p=0.03\right)$. A search for may Vinf and might Vinf in the legal cross-examinations and personal letters sections of ICE-GB (Wallis 2006), a corpus of late $20^{\text {th }}$ century BrE, shows that the two variants are equally frequent (11 tokens for both may Vinf and might Vinf). The difference between $19^{\text {th }}$ century EngE and late $20^{\text {th }}$ century EngE is also statistically significant $\left(X^{2}=17.02, d f=1, p=0.0002\right)$. Thus, the EngE data seem to show the development of might Vinf from a minority variant at the start of the $19^{\text {th }}$ century to a major variant at the end of the $20^{\text {th }}$ century.

Figure 1. Non-past, non-remote subjective possibility in IrE and EngE (proportional distribution with error bars) 

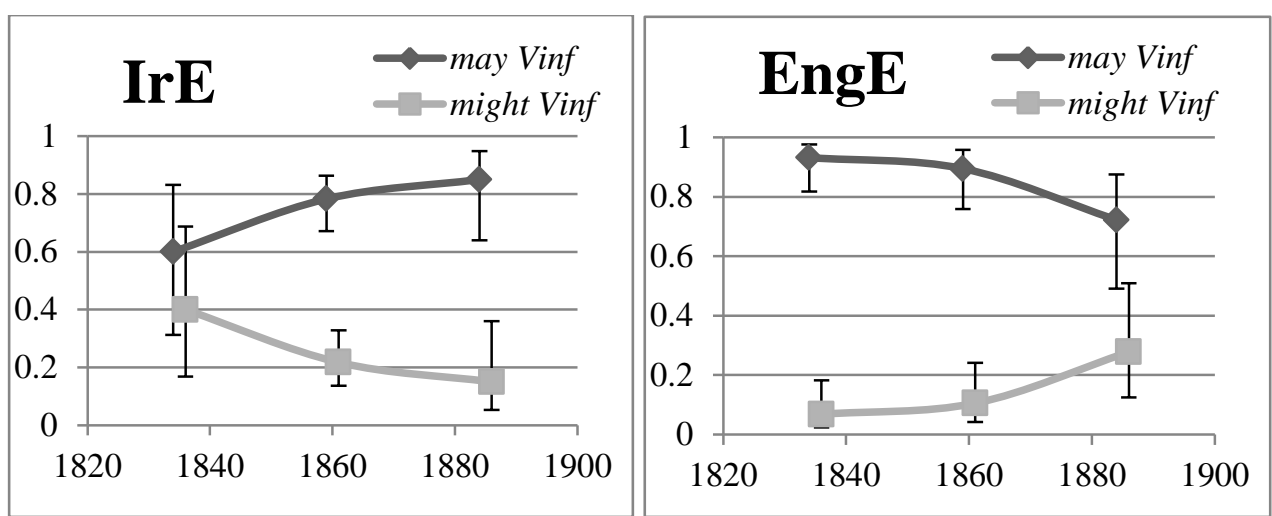

In IrE, on the other hand, the two variants seem to be almost equally frequent at the start of the $19^{\text {th }}$ century, and may Vinf becomes more frequent towards the end of the century. Though the total number of tokens for IrE at the start of the $19^{\text {th }}$ century is low, the difference between IrE and EngE in this period is nevertheless statistically significant $\left(X^{2}=7.95\right.$, $\mathrm{df}=1, p=0.017$ ). ICE-Ireland (Kirk \& Kallen 2008), the Irish equivalent of ICE-GB, has twelve instances of may Vinf in this context in the legal crossexaminations and personal letters sections, and twelve instances of might Ving. This suggests that in present-day $\operatorname{IrE}$ the two variants are equally frequent in this context. The data indicate that the use of might Vinf in IrE shifted from being a minority variant towards the end of the $19^{\text {th }}$ century to a one of two major variants in the late $20^{\text {th }}$ century $\left(X^{2}=5.95, d f=1, p=0.02\right)$.

Thus, both the IrE and EngE data show how might gradually loses its ability to signal past time from the early $19^{\text {th }}$ century to the late $20^{\text {th }}$ century. The OED quotes a first instance of might Vinf in this context from 1859 (example (32)). This suggests that the IrE data in particular seem to be quite 
progressive when it comes to the development of might Vinf in non-past, non-remote contexts.

(32) I might not have the hopefulness to do it for weeks. I might ... have that hopefulness to-morrow (OED, s.v. may $\left.\mathrm{v}^{1}, 26 \mathrm{~b}\right)$

\subsection{2 - M/past - P/past + remote}

As could be seen in Table 4 above, both may Vinf and might Vinf can express subjective possibility in contexts where the proposition is non-past and remote, as in (33), where the speaker alternates between may Vinf and might Vinf within one utterance. In this example, the clauses preceding the ones with the modal verbs contain conditions which have to be met in order for the propositions of the modals to become possible. Since the conditions in the protasis are set at the time of the utterance, both the modal possibility and the proposition have non-past readings.

(33) If he admits the cause of action by paying money into Court or if there is a verdict against him on this part of the case, he may be obliged to take built by him down and indeed as the trespass is a continuing one a new action might be brought for it (OBC, Holmes 1875) 
According to the OED (s.v. may $\left.\mathrm{v}^{1}, 13 ; 20\right)$, might Vinf has been used in this context since at least the ME period, but may Vinf has only been found in this context since the early $19^{\text {th }}$ century. Apparently, the use of may Vinf in this context was criticised by $20^{\text {th }}$ century prescriptivists, which might explain why PDE accounts of may and might often lack a discussion of may Vinf in non-past remote contexts. However, it seems the data in for instance the work of Coates (1983) does record at least one instance (see example (34)). Visser (1969:1769-1770) does not distinguish between may Vinf in non-past remote and non-remote contexts and includes instances such as (35) in his paragraph on subjective possibility may Vinf.

(34) be quite certain that you hold it very definitely there because if it does slip out you may well have a baby (Coates $1983: 135)$

(35) If I ask him again, he may refuse (Visser 1969:1770)

The non-past remote subjective possibility context does not occur very frequently in the corpus, but the data does show that the two forms are both major variants in the $19^{\text {th }}$ century. May Vinf is used four times in the IrE data and eight times in the EngE data, and might Vinf is used eleven times in the IrE corpus and six times in the EngE corpus (see Table 4). Might Vinf is used more frequently in the IrE dataset (73\% against $43 \%$ in EngE), but the difference is not statistically significant. In addition, four of the IrE might 
Vinf tokens are produced by a single author, John McCance, a farmer from county Down. Thus it seems that McCance's idiolect is slightly skewing the IrE results.

\subsection{3 -M/past $+P /$ past -remote}

The expression of subjective possibility in contexts where the modality has non-past time reference and the proposition has past time reference shows the most variation out of the contexts discussed in this paper. The corpus contains four different forms which can be used: (i) may Ving (example (36)); (ii) might Vinf (example (37)); (iii) may have Ven (example (38)); and might have Ven (example (39)). In all examples the subjective possibility judgement is made in the act of speaking, making the modality non-past, but the proposition holds at some stage in the past, creating a back-shifted interpretation relative to the time of speaking.

(36) I knew Mr. Day at the end of August, 1878, since then I have once been to Bow street on his behalf, and it may be a dozen times in other matters affecting Craven and Bell, but not affecting Mr. Day (OBC, T1878118)

(37) I sat down near her, and had a pint of ale - some other persons came in - I might be two hours in their company (OBC, T18260914) 
(38) I may have done so once, but I don't remember (OBC, le Hunt Doyle 1877)

(39) I might have been having a little on different occasions, but I knew what I was doing (OBC, Johnson 1847)

Figure 2 shows the proportional distributions of the development of the four dependent variants in the EngE and IrE data sets combined. May Vinf is a minority variant and is found only five times in the corpus, once in the $\operatorname{IrE}$ dataset and four times in EngE. As can be seen in example (36) above, the form is entirely dependent on the context to cause a back-shifted interpretation. The co-ordinate clause since then I have once been to Bow Street suggests that it may be a dozen times could be paraphrased by 'it is possible that it has been a dozen times'. All examples of this construction in the corpus are formed with the lexical verb be. Thus, it is possible that there is contamination from the adverb maybe, which does not carry temporal reference.

Figure 2. Non-past subject possibility with past non-remote propositions in EngE and IrE combined 


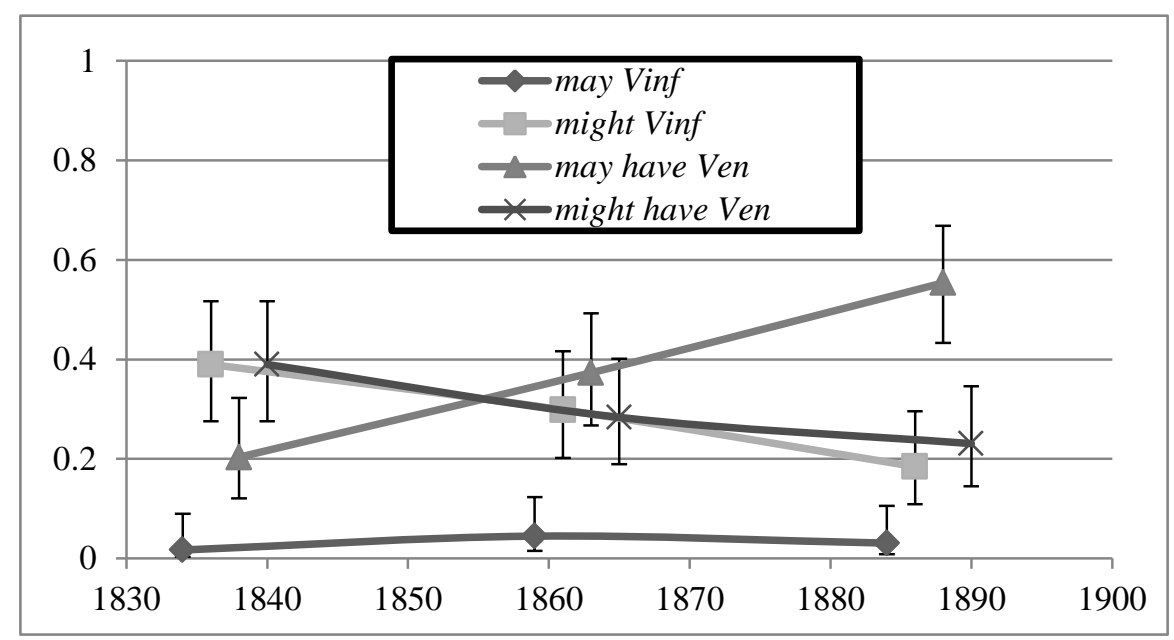

Might Vinf is one of the major variants at the start of the $19^{\text {th }}$ century. In Van Hattum (2012a) I proposed that in instances such as example (37) above the tense of the modal affects the time reference of the proposition and creates a back-shifted interpretation relative to the time of the utterance. This means that for speakers who have this form as part of their dialect in this context, the modal verb might has not yet lost the ability to signal past time reference.

The form occurs quite frequently at the start of the $19^{\text {th }}$ century but significantly declines towards the end $\left(X^{2}=5.93, d f=1, p=0.05\right)$. A search for these contexts in ICE-GB and ICE-Ireland finds no instances of might Vinf in this context in the legal cross-examinations and personal letters sections of these two corpora, which supports the claim in the OED that they have become rare or perhaps even obsolete in PDE (cf. Section 2.2). Thus, the data show how might gradually lost its ability to signal past time reference 
in this context throughout the $19^{\text {th }}$ and $20^{\text {th }}$ centuries. The development of might Vinf is similar in IrE and EngE, as the difference between the two varieties is never statistically significant. However, it is perhaps interesting to note that forms with might are again more frequent in the IrE dataset.

At the start of the $19^{\text {th }}$ century may have Ven was used slightly less frequently than might Vinf and might have Ven. However, towards the end of the $19^{\text {th }}$ century may have Ven is the favoured variant when expressing non-past subjective possibility with a back-shifted interpretation of the proposition in non-remote contexts. Thus, the data in the corpus support the claim in the OED (s.v. may $\left.\mathrm{v}^{1}, 7 \mathrm{c}\right)$ that may have Ven replaces might Vinf in this context. In addition, the data indicates that this replacement was a gradual process which took place largely in the $19^{\text {th }}$ century.

As mentioned above, the replacement seems to have been completed towards the end of the $20^{\text {th }}$ century. May have Ven was clearly favoured by late $19^{\text {th }}$ and early $20^{\text {th }}$ century commentators on the grounds that this form was more logical because it involves a judgement in the present about a past event (cf. OED, s.v. may v ${ }^{1}, 18 b$; Visser 1969: 1776). This claim would only make sense if the commentators considered might to be a past time carrier in the might Vinf construction and, thus, lends support to my previous claim that might in this form causes the back-shifted interpretation of the proposition.

Might have Ven is one of the most frequently used variants at the start of the $19^{\text {th }}$ century in a context where the subjective possibility is non-past 
and the proposition has a back-shifted interpretation. Figure 2 shows a slight decrease in the use of might have Ven in this context, but the decrease is not statistically significant. A search in ICE-GB and ICE-Ireland reveals that may have Ven and might have Ven seem to be used almost equally frequently in PDE, with 14 and 10 instances respectively.

According to Visser (1969), might have Ven is used in counterfactual contexts only and he does not report its use in non-counterfactual contexts. Visser (1969), relying on Wood (1963), claims that may have Ven expresses a possibility which still exists in the absence of information to the contrary, whereas might have Ven suggests that a past possibility no longer exists in the present. As mentioned in Section 2.2, the OED does acknowledge that might have Ven can refer to possibilities which still exist and records an example from 1847 as its first quotation. My corpus contains several instances which predate the first quotation of the OED, such as (40) from 1825, and Van Hattum (2012b) records (41) from 1768. In addition, the frequency of occurrence of might have Ven relative to the other forms in this context does not suggest a newly emerging form.

(40) I spoke quite loud and Cole might have heard it (OBC, T18250113)

(41) A: Was your sister reputed to be a woman of the town? 
B: She might have had a misfortune to be sure; I do not know what you mean by a woman of the town, she was unfortunate (OBC, T17681019)

\subsection{4 + M/past + P/past -remote}

The corpus contains a total of 39 instances of subjective possibility may and might in a context where the sequence-of-tense rule creates a past time reference for the modality and the proposition. This particular context shows three different variants: (i) may Vinf as in (42); (ii) might Vinf as in (43); and might have Ven as in (44), though will be discussed later, these variants are not always interchangeable. 
(42) You was pulling me towards another man; I said there was another man may have it as well as me (OBC, T18371127)

(43) the woman pushed him into the house and told him to hold his tongue, as he did not know who might be listening to him (OBC, Barrett 1842)

(44) I took it out and found it was a print of Ely chapel, which I missed from a book I had to bind; I thought he might have taken it out to shew his father, who lives near Ely chapel (OBC, T18270405)

Example (42) shows may followed by the infinitive of the lexical verb, which suggests a failure of sequence of tenses in indirect speech. Joyce (1910) mentions a 'peculiar' IrE expression involving sentences such as (42), where the present tense modal verb may is used instead of the past tense from might. He reports that he has "heard and read, scores of times, expression of which this is a type - not only among peasantry, but from newspaper correspondents, professors, \&c. - and you can hear and read them from Munstermen to this day in Dublin" (Joyce 1910:84). However, the one instance, example (42), is found in the EngE dataset, not the $\operatorname{IrE}$ one, which does not give Joyce's claim that this feature is peculiar to $\operatorname{IrE}$ any support. Wood (1963) warns against using may as a past tense in this context and claims that this 'mistake' can be frequently found in certain 
parts of England. Denison (1991) also mentions the existence of this construction in present-day EngE and suggests several possible explanations, including a general weakening of the sequence of tense rules. Another explanation offered concerns may being mistaken for a past tense form, proposing that for some speakers may and might are not different tense forms of the same lexeme. This explanation supports the idea that may and might were losing their ability to signal time reference.

The two other variants, might Vinf and might have Ven, do not seem to be interchangeable in this context. The might Vinf form, as in example (43) above, has a modal time which is in the past in order to comply with sequence-of-tense, and the time of the proposition in this case coincides with the modal time, though there are also instances where the time of the proposition has a future orientation relative to the modal time, as in example (45). All instances of might have Ven in this context (e.g. (44) above) also have a past modal time, but the time of the proposition is back-shifted relative to the modal time. Though the two forms are not interchangeable, it does seem that might in both forms still signals past time.

(45) I said I might perhaps obtain a copy and would endeavour to do so by Monday evening (OBC, Rogers 1876)

Might Vinf has been used to express past subjective possibility with a coinciding or future-oriented proposition since at least the $16^{\text {th }}$ century, and 
the data in Visser (1969) suggests that this form was also used to express past subjective possibility with a back-shifted proposition. The quotations in the OED (s.v. may $v^{1}, 18 \mathrm{c}$ ) indicate that it was not until the late $18^{\text {th }}$ century that might have Ven started to replace might Vinf in contexts with a backshifted proposition, though Van Hattum (2012b) records an instance from 1738 (example (46)).

(46) I told them it might possibly have been in my Possession; for I had several Notes upon Goldsmiths, and upon the Bank, in my Possession (OBC, T17380906)

The variation in the corpus between may Vinf, might Vinf, may have Ven, and might have Ven in subjective possibility contexts indicates that might increasingly occurs without the ability to signal past time reference. This tendency is signalled in non-past and non-remote contexts where might Vinf increases its use relative to may Vinf throughout the $19^{\text {th }}$ and $20^{\text {th }}$ centuries. In addition, we can see that might Vinf is being replaced by may have Ven in contexts where the modality is in the present, but the proposition is in the past.

Figure 3 below shows the proportional distribution of might as an unambiguous past or present time marker in subjective possibility contexts. Might as an unambiguous past tense marker includes might Vinf and might have Ven in contexts where the modality and the proposition are both in the 
past, as in examples (43) and (44) respectively, and instances of might Vinf where the modality is non-past and the proposition is past, as in example (37). Might as an unambiguous present time marker in subjective possibility contexts includes might Vinf in non-remote contexts where the modality and the proposition are non-past (e.g. (31) above). The Figure shows that the development of might as a present tense marker, and the loss of the ability to signal past time reference, progresses faster in IrE in comparison to EngE. By the mid-nineteenth century, might is used equally often to signal past and present time reference in IrE, whereas in EngE might is still used significantly more often to signal past time reference in comparison to present time reference, as indicated by the error bars. The difference between IrE and EngE in the second half of the nineteenth century is statistically significant $\left(X^{2}=8.30, d f=1, p=0.01\right)$.

Figure 3. Might as unambiguous past or present time marker in $\operatorname{IrE}$ and EngE (proportional distribution with error bars)

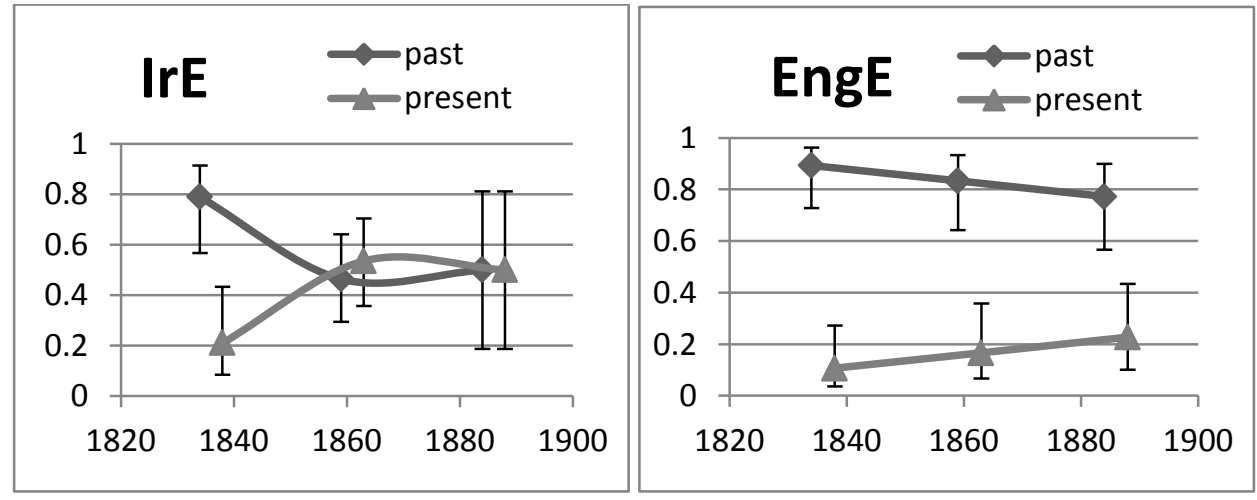

\section{Discussion}


In objective possibility contexts, the variation between may Vinf, might Vinf and might have Ven suggests that may is most commonly used in non-past contexts without remoteness interpretations, might is generally found in either past time or remote contexts, or a combination of the two. The only contexts in which might seems to have lost its ability to signal past time is in formulaic expressions such as I might say or I might mention, and in counterfactual contexts. The apodosis of an unreal conditional requires a modal verb in the past tense (e.g. Palmer 1990, Mezhevich 2008), so a perfect is needed to signal an additional past time reference. However, as mentioned above, counterfactuals are often indeterminate or even merged between objective and subjective possibility. Thus, it seems that in $19^{\text {th }}$ century IrE and EngE, when may and might are used to express objective possibility, may is used in non-past and non-remote contexts, and might is used in either past or remote contexts, as is the case in PDE. The only difference between the IrE and EngE datasets seems to be that $\operatorname{IrE}$ makes more use of formulaic expressions such as I might say.

The subjective possibility data, on the other hand, suggest that might increasingly lost its ability to signal past time reference throughout the $19^{\text {th }}$ and $20^{\text {th }}$ centuries. I propose that this loss of might to signal past time reference is tied to the grammaticalisation of the general perfect construction. With the shift from a synthetic to an analytical morphology within the verb phrase a number of periphrastic constructions came to 
alternate with the preterite. According to Tagliamonte (2000: 335) periphrastic constructions with have were present in $\mathrm{OE}$, but the functional distinctions of the perfect did not become well-established until the ME period and beyond. The perfect gradually diffused into more and more linguistic contexts and encroached on the domain of the preterite throughout the late ME and Modern English periods (McFadden \& Alexiadou 2010). With the perfect becoming increasingly used to create back-shifted interpretations relative to the utterance time, it would make sense that a modal + perfect construction would develop in subjective possibility contexts.

As discussed above, in earlier varieties of English might Vinf was used in contexts where the time of the proposition had a back-shifted orientation relative to the time of the utterance. Since subjective possibility judgments are generally made in the act of speaking, the modal time would be simultaneous to the time of the utterance. Thus, in a might Vinf construction, might would signal the time reference of the proposition, but it could not signal the time reference of the modality, which was entirely dependent on context. It might, therefore, make sense that the perfect would extend to verb groups with modal verbs expressing subjective possibility, so that the perfect could create a back-shifted interpretation for the proposition, and the modal verb could signal the time reference of the modality, giving rise to may have Ven. 
According to the OED and Visser (1969), the use of might in non-past and non-remote contexts developed out of the use of might in non-past remote contexts. In the earlier stages, might in non-past contexts occurred in conditional sentences only, but gradually it started to appear in sentences where the accompanying conditional clause is not present, but implied by another element in the sentence; for example, in (47) the condition is not explicit but implied by the phrase to tell that, meaning 'if I were to tell that'. From there, its use was extended to non-past, non-remote contexts, where no condition was present, either explicit or implied. It has been suggested that at first this use was considered to be more tentative than may, but now may and might are commonly considered indistinguishable (cf. Visser 1969, Coates 1983, Palmer 1990, OED).

(47) What is thine own name and lineage? To tell that ... might reveal my master's (OED, s.v. may $\left.\mathrm{v}^{1}, 21 \mathrm{a}\right)$

As might became less and less restricted to past and remote contexts, and the perfect could now create a back-shifted interpretation relative to the utterance time, might was free to signal present time reference in combination with a perfect in the might have Ven construction. This meant that might have Ven could now be extended from counterfactual contexts, where might signals remoteness and the perfect causes a back-shifted interpretation, to non-counterfactual contexts where the modal time is non- 
past, as signalled by the modal verb, and the proposition is past, as signalled by the perfect.

The development of the expression of time reference with modal verbs can be summarised in six main points:

1. might can be used in non-past contexts to signal remoteness;

2. the rise of the present perfect allows for the analytical morphology of might have Ven in counterfactual contexts and may have Ven in noncounterfactual contexts where the tense of the modal verb signals the time of the modality and the perfect creates a back-shifted orientation for the proposition;

3. might extends from explicit conditionals to implied conditionals;

4. might extends from implied conditionals to non-past, non-remote contexts;

5. might have Ven extends from counterfactual contexts to pluperfect contexts where might signals the past interpretation of the modality and the perfect signals the back-shifted orientation of the proposition relative to the modal time;

6. might have Ven extends from counterfactual past contexts to noncounterfactual past contexts, as might no longer assigns past time or remoteness to the modality.

The $19^{\text {th }}$ century data in the study show signs of the increasing use of may have Ven (step 2), the extension of might to non-past and non-remote 
contexts (step 4), the use of might have Ven in pluperfect contexts (step 5), and a relatively stable use of might have Ven outside counterfactual and pluperfect contexts before becoming one of two major variants in these contexts (step 6).

There seems to be little difference in the status of subjective possibility may and might in the $19^{\text {th }}$ century between EngE and IrE. The only statistically significant difference is the high use of subjective possibility might Vinf in non-past and non-remote contexts in the early $19^{\text {th }}$ century. Dollinger (2008) has found that long term changes in the modal verb system seem to be relatively unaffected by transportation of the English language to overseas colonies. Since the capacity of the modals to signal past time reference has been eroding since at least the OE period with the extension might to non-past remote contexts, this could be another case study which corroborates Dollinger's (2008) findings.

However, when looking at subjective possibility context as a whole, the distribution of might variants in contrast with may variants is higher in IrE than in EngE. In addition, in non-remote contexts, might is used increasingly more often to signal present time in contrast with past time, especially in the second half of the $19^{\text {th }}$ century. In EngE, might is used more frequently as an unambiguous past time marker as opposed to a present time marker throughout the $19^{\text {th }}$ century, though the use of might to signal present time does increase slightly. As explained in the introduction, there was a large increase in native Irish speakers shifting to English 
throughout the $19^{\text {th }}$ century, but in particular towards the second half of the century. In Irish, the construction most frequently used for expressing subjective possibility is the copula followed by féidir where the copula is generally in the past tense/conditional form, i.e. b' fhéidir (Ó Siadhail 1989). Thus, the relatively high use of the past tense/remote form might in IrE might have been caused by a parallel preference for the past/tense conditional in the Irish language.

\section{Conclusion}

The aim of the present paper was to investigate the status of the loss of might to signal past time reference, and the consequent constructions that arose as a result, in $19^{\text {th }}$ century IrE and EngE. I investigated the relationship between constructions involving objective and subjective possibility, may and might, and their temporal properties by analysing the time reference of the modal verb, the time reference of the proposition and the remoteness of the proposition. The $19^{\text {th }}$-century tokens under analysis were retrieved from a database used for the study of modal verbs in IrE from the $14^{\text {th }}$ to the $20^{\text {th }}$ centuries, which was based on a self-compiled corpus of historical IrE and EngE trial proceedings and personal letters (cf. Van Hattum 2012b).

It was found that in objective possibility contexts, might was still restricted to either past or remote contexts, whereas may was used only in 
non-past and non-remote contexts. The only exceptions to this general tendency were formulaic expressions such as I might say, which occurred more frequently in IrE than in EngE, and the counterfactuals which were claimed to form a category in between objective and subjective possibility.

In subjective possibility contexts, it was found that in both IrE and EngE might increasingly lost its ability to signal past time reference; that is, (i) may have Ven was increasingly used in contexts where a present subjective judgement is made about a proposition which took place at some time in the past; and (ii) might was increasingly used outside of either past time or remote contexts. I proposed that the loss of might to signal past time reference in subjective possibility contexts was tied to the grammaticalisation of the perfect construction, which took over the responsibility to signal past time reference from might. I argued that this could happen in subjective possibility contexts only, since subjective possibility judgements themselves are generally made in the present, so it would make more sense to have the modal verb itself signal present time and the perfect signal past time. Hypothetical might then gradually extended its use beyond past and remote contexts, making its inability to signal past time reference complete and allowing for the interchangeability that has developed between may and might in both present and past time contexts. Thus, it seems that this process is generally tied to grammaticalisation and semantic bleaching, but the influence of prescriptive attitudes in favour of the may have Ven form might have also played a role. The development of 
may and might in subjective possibility contexts in IrE is similar to EngE. However, there were some differences between the two varieties. In the early $19^{\text {th }}$ century might is found more often in non-past, non-remote contexts in the IrE dataset than in the EngE set. In addition, it seems that might loses its ability to signal past time reference in subjective possibility contexts, and thus increases its frequency of us in non-past, non-remote contexts, earlier in IrE than in EngE. I suggested that this higher frequency might be the result of Irish influence where the past tense/conditional form b' fhéidir 'perhaps' is preferred over the present tense form is féidir in nonpast, non-remote contexts.

To sum up, it seems that the expression of past time reference with may and might in objective possibility contexts was stable throughout the $19^{\text {th }}$ century, whereas the subjective possibility data showed substantial change in both IrE and EngE. Changes in the main constructions discussed in this chapter are thus attributable to both diachronic and regional influences.

\section{References}

Coates, Jennifer. 1983. The Semantics of the Modal Auxiliaries. London: Croom Helm.

Condoravdi, Cleo. 2002. Temporal interpretation of modals: Modals for the present and past. In Construction of Meaning, David I. Beaver, Luis D. 
Casillas Martínez, Bradley Z. Clark \& Stefan Kaufmann (eds), 59-88. Stanford, CA: CSLI.

Demirdache, Hamida \& Uribe-Etxebarria, Myriam. 2008. On the temporal syntax of non-root modals. In Time and Modality, Jacqueline Guéron \& Jacqueline Lecarne (eds), 79-113. Berlin: Springer. <http://www.springer.com/philosophy/book/978-1-4020-8353-2> (accessed 5 August 2011)

Denison, David. 1991. Counterfactual may have. In Internal and External Factors in Syntactic Change, Marinel Gerritsen \& Dieter Stein (eds), 229-256. Berlin: Mouton de Gruyter.

Denison, David. 1993. English Historical Syntax. London: Longman.

Dennett, Maurice. 1990. The Cherry Valley Chronicles. Letters from Thomas Buckley of Massachusetts to Ralph Buckley of Saddleworth 1845-1875. Saddleworth Historical Society.

Dollinger, Stefan. 2008. New-Dialect Formation in Canada. Evidence from the English Modal Auxiliaries. Amsterdam: John Benjamins.

Facchinetti, Roberta. 2003. Pragmatic and sociological constraints on the functions of 'may' in contemporary British English. In Modality in Contemporary English, Roberta Facchinetti, Manfred Krug \& Frank R. Palmer (eds), 301-327. Berlin: Mouton de Gruyter.

Filppula, Markku. 1999. The Grammar of Irish English: Language in Hibernian Style. London: Routledge. 
Fitzpatrick, David. 1994. Oceans of Consolation: Personal Accounts of Irish Migration to Australia. Cork: Cork University Press.

Fritz, Clemens. 2004. A Corpus of Oz Early English (COOEE). Free University of Berlin.

Fritz, Clemens. 2007. From English in Australia to Australian English 1788-1900. Frankfurt am Main: Peter Lang.

Hitchcock, Tim, Shoemaker, Robert, Emsley, Clive, Howard, Sharon \& McLaughlin, Jamie, et al. 2012. The Old Bailey Proceedings Online, 1674-1913. <www.oldbaileyonline.org, version 7.0> (accessed 24 March 2012).

Huber, Magnus. 2007. The Old Bailey Proceedings, 1674-1834. Evaluating and Annotating a Corpus of $18^{\text {th }}$ - and $19^{\text {th }}$-century Spoken English. Varieng 1. 〈www.helsinki.fi/varieng/journal/volumes/01/huber> (accessed 20 March 2010).

Huber, Magnus, Nissel, Magnus, Maiwald, Patrick \& Widlitzki, Bianca. 2012. The Old Bailey Corpus. Spoken English in the $18^{\text {th }}$ and $19^{\text {th }}$ centuries. <www.uni-giessen.de/oldbaileycorpus> (accessed 4 July 2013).

Joyce, Patrick W. 1910. English as We Speak It in Ireland. Dublin: Wolfhound.

Kirk, John M. \& Kallen, Jeffrey L. 2008. ICE-Ireland. Queen's University Belfast, Trinity College Dublin and Cló Ollscoil na Banríona. 
Lightfoot, David W. 1979. Principles of Diachronic Syntax. Cambridge: Cambridge University Press.

McCafferty, Kevin \& Amador-Moreno, Carolina P. Under construction. Corpus of Irish English Correspondence (CORIECOR). Bergen, Norway.

McFadden, Thomas \& Alexiadou, Artemis. 2010. Perfects, resultatives, and auxiliaries in Earlier English. Linguistic Inquiry 41(3): 389-425.

Mezhevich, Ilana. 2008. A time-relational approach to tense and mood. In Proceedings of the $27^{\text {th }}$ West Coast Conference of Formal Linguistics. Natasha Abner \& Jason Bishop (eds), 326-334. Somerville, MA: Cascadilla Proceedings Project.

Ó Siadhail, Mícheál. 1989. Modern Irish. Grammatical Structure and Dialectal Variation. Cambridge: Cambridge University Press.

OED Online. 2012. The Oxford English Dictionary. Oxford: Oxford University Press <www.oed.com> (accessed 22 May 2014).

Palmer, Frank R. 1990. Modality and the English Modals. London: Longman

Sedgefield, Walter J. (ed). 1900. King Alfred's Version of the Consolations of Boethius. Done into Modern English. Oxford: Clarendon Press.

Tagliamonte, Sali A. 2000. The grammaticalization of the present perfect. Tracks of change and continuity in a linguistic enclave. In Pathways of Change. Grammaticalization in English, Olga Fischer, Anette 
Rosenbach \& Dieter Stein (eds), 328-354. Amsterdam: John Benjamins.

Traugott, Elizabeth C. 1972. The History of English Syntax. New York: Holt, Rinehart and Winston.

Traugott, Elizabeth C. 2006. Historical aspects of modality. In The Expression of Modality, William Frawley, Erin Eschenroeder, Sarah Mills \& Thao Nguyen (eds), 106-139. Berlin: Mouton de Gruyter.

Van der Auwera, Johan \& Plungian, Vladimir. 1998. Modality's semantic map. Linguistic Typology 2:79-124.

Van Hattum, Marije. 2012a. "A cannot get a loan for more than six years now". The relationship between modal verbs and past time reference in Irish English. In New Perspectives on Irish English, Bettina Migge \& Máire Ní Chiosáin (eds), 131-152. Amsterdam: John Benjamins.

Van Hattum, Marije. 2012b. Irish English modal verbs from the fourteenth to the twentieth centuries. $\mathrm{PhD}$ dissertation, The University of Manchester, UK.

Visser, Frederik Th. 1969. An Historical Syntax of the English Language, Vol. 3.1: Syntactical Units with Two Verbs. Leiden: E. J. Brill.

Wallis, Sean. 2006. ICECUP 3.1. Survey of English Usage, University College London, UK.

Warner, Anthony R. 1993. English Auxiliaries: Structure and History. Cambridge: Cambridge University Press.

Wood, Frederick T. 1963. Current English Usage. London: Macmillan. 
Yáñez-Bouza, Nuria. 2011. ARCHER: past and present (1990-2010). ICAME Journal 35: 205-236. 